\section{Tomato Fruit Quality and Shelf Life in Hybrids Heterozygous for the alc Ripening Mutant}

\author{
Martha A. Mutschler ${ }^{1}$, David W. Wolfe ${ }^{2}$, Edward D. Cobb ${ }^{1}$, and \\ Kenneth S. Yourstone ${ }^{2}$ \\ Cornell University, Ithaca, NY 14853
}

Additional index words. alcobaca, storage, Lycopersicon esculentum

\begin{abstract}
Fruit of tomato (Lycopersicon esculentum Mill.) hybrids heterozygous for the alc ripening mutation stored on average $60 \%$ (3.6 days) longer at $20 \mathrm{C}$ than that of their normal-ripening parents. There were no detrimental effects of the alc heterozygous condition on fruit color, firmness, or size. The background into which alc was introduced also affected fruit quality and shelf life. These results indicate hybrids heterozygous for the alc ripening mutant can produce commercially acceptable fruit with significantly longer shelf life than their normal-ripening parents.
\end{abstract}

Fresh-market tomatoes often have poor consumer quality, which is due in part to the marketing procedures used. Fruit are picked green and ripening is initiated by ethylene treatment. This procedure can produce acceptable fruit when tomatoes are picked mature-green, but frequently immature green fruit are also harvested. The immature green fruit will develop red pigmentation without acquiring the flavor, texture, and quality of a vine-ripe tomato (Kader et al., 1977).

The commercial practice described above was developed to facilitate tomato harvest, prolong fruit shelf life, and minimize physical damage to the fruit during handling. Use of the ripening mutant genes rin (ripening inhibitor), nor (nonripening), $\mathbf{N r}$ (never-ripe), and alc (Alcobaca) in the heterozygous condition offers the possibility of picking fruit at early stages of red pigment development,

Received for publication 5 Apr. 1991. Accepted for publication 12 Nov. 1991. This work was funded in part through Hatch Project 149484 and U.S. Dept. of Agriculture. Competitive Grant no. 87CSCR-I-2436. The cost of publishing this paper was defrayed in part by the payment of page charges. Under postal regulations, this paper therefore must be hereby marked advertisement solely to indicate this fact.

Dept. of Plant Breeding and Biometry. Author to whom reprint requests should be addressed.

${ }^{2}$ Dept. of Fruit and Vegetable Sciences. thereby ensuring harvest of mature fruit, and yet having adequate shelf life (Kopeliovitch and Rabinowitch, 1979; McGlasson et al., 1983; Tigchelaar et al., 1978). By avoiding the harvest of immature fruit, tomato quality could be improved and made more reliable.

Ripening of rin heterozygotes is delayed in initiation and proceeds slowly compared to that of the normal-ripening fruit (McGlasson et al., 1987). Fruit of $F_{1}$ lines heterozygous for $\boldsymbol{r i n}$ have lower rates of softening (Aly et al., 1986a; McGlasson et al., 1987) and show longer shelf life than isogenic homozygous normal-ripening controls (Aly et al., 1986b). Fruit of nor heterozygotes also displayed delayed softening and extended storage life compared to normal-ripening fruit (Buescher et al., 1976). Organoleptic tests of fruit of rin and nor heterozygotes and their normal ripening parent, Rutgers, demonstrated that heterozygosity for either mutant had deleterious effects on fruit flavor, but that effects of the rin heterozygote condition on flavor were slight, and the effects of the nor heterozygote condition were considerably more severe (Kopeliovitch et al., 1982).

The Alcobaca ripening mutant (alc) is controlled by a single gene that is located on the short arm of chromosome 10 (Mutschler, 1984a). The gene slows ripening of the fruit between the mature-green and ripe stages and extends shelf life such that heterozygous and homozygous fruit have shelf lives of $\approx 14$ and 35 days, respectively, compared to the 9-day shelf life for the normal-ripening tomatoes. The extended shelf life of the alc homozygotes and heterozygotes is associated with a decrease in the rate at which the fruit continue to soften after they are ripe, rather than with a higher initial firmness of ripe fruit (Mutschler, 1984b). The alc mutant affects pigment synthesis, reducing total pigment produced and reducing the lycopene : beta-carotene ratio. It also reduces the levels of polygalacturonase protein and total activity in fruit homozygous for alc (Mutschler, 1984b; Mutschler et al., 1988). The levels of mRNA homologous to 14 ripening-specific and -related genes in pericarp of fruit homozygous for alc are reduced to $10 \%$ to $66 \%$ of that of normal-ripening fruit, depending on the gene of interest (Mutschler et al., 1988). Regions homologous to the 14 ripening-specific and -related genes whose expression were affected by alc were mapped to 27 sites on 12 chromosomes using restriction fragment length polymorphisms (Kinzer et al., 1990). There was no evidence of clustering of the ripening loci or of linkage of any of the ripening-specific genes to alc. This indicates that the effects of alc on the levels of ripening-specific mRNAs must be transactive.

The previous results showing improved shelf life in alc heterozygotes were obtained using hybrids made with the original landrace, Alcobaca, which has poor horticultural type, including fruit that are small, puffy, and soft (Mutschler, 1984b). Research reported here was done to determine whether commercially acceptable hybrids heterozygous for alc would have sufficient increases in shelf life to be useful for fresh-market tomato production.

A series of breeding lines of good horticultural quality and homozygous for alc was created through an inbred-backcross program (M. A.M., unpublished). Four of the best alc-homozygous lines, 86-261-6,86-248$7,86-269-8$, and 86-268-3, were used in crosses with two normal-ripening lines, 'Piedmont' (Gardner, 1985) and a Cornell breeding line 86-35-4 (M. A.M., unpublished) to create eight experimental hybrids heterozygous for alc. The normal-ripening 
Table 1. Means of weight, $L$ value, a/b ratio, firmness, and shelf life of fruit from parent and $F_{1}$ plants in 1987 and 1988.

\begin{tabular}{|c|c|c|c|c|c|c|c|c|c|c|c|c|}
\hline \multirow{3}{*}{$\begin{array}{l}\text { Type of } \\
\text { plants }\end{array}$} & \multirow[b]{3}{*}{ Parent $1^{y}$} & \multirow[b]{3}{*}{ Parent $2^{y}$} & \multirow{2}{*}{\multicolumn{2}{|c|}{ Wt (g) }} & \multicolumn{4}{|c|}{ Fruit color ${ }^{2}$} & \multirow{2}{*}{\multicolumn{2}{|c|}{$\begin{array}{c}\text { Deformation } \\
(\mathrm{mm})\end{array}$}} & \multirow{2}{*}{\multicolumn{2}{|c|}{$\begin{array}{c}\text { Shelf life } \\
\text { (days) }\end{array}$}} \\
\hline & & & & & \multicolumn{2}{|c|}{ L value (\%) } & \multicolumn{2}{|c|}{$\mathrm{a} / \mathrm{b}$ ratio } & & & & \\
\hline & & & 1987 & 1988 & 1987 & 1988 & 1987 & 1988 & 1987 & 1988 & 1987 & 1988 \\
\hline \multirow[t]{2}{*}{$F_{1}$} & $\begin{array}{l}86-261-6 \\
86-248-7 \\
86-269-8 \\
86-268-3\end{array}$ & & 1 & $\begin{array}{l}197 \\
183 \\
171 \\
168\end{array}$ & $\begin{array}{l}48.4 \\
50.0 \\
48.9 \\
48.8\end{array}$ & $\begin{array}{l}49.6 \\
49.7 \\
49.7 \\
49.4\end{array}$ & $\begin{array}{l}0.59 \\
0.47 \\
0.54 \\
0.56\end{array}$ & & & & $\begin{array}{r}10.2 \\
14.1 \\
10.2 \\
7.7\end{array}$ & $\begin{array}{r}8.2 \\
9.0 \\
10.6 \\
10.2\end{array}$ \\
\hline & & $\begin{array}{l}\text { Piedmont } \\
\text { Piedmont } \\
\text { Piedmont } \\
\text { Piedmont }\end{array}$ & $\begin{array}{l}185 \\
263\end{array}$ & $\begin{array}{l}209 \\
188 \\
180 \\
167\end{array}$ & $\begin{array}{l}48.7 \\
49.5 \\
48.8 \\
48.4\end{array}$ & $\begin{array}{l}49.0 \\
50.5 \\
52.0 \\
50.9\end{array}$ & $\begin{array}{l}0.56 \\
0.50 \\
0.58 \\
0.60\end{array}$ & & & & $\begin{array}{r}10.7 \\
11.5 \\
9.5 \\
10.2\end{array}$ & $\begin{array}{r}10.4 \\
8.9 \\
10.7 \\
10.3\end{array}$ \\
\hline rent & $\begin{array}{l}86-2 \\
86-2 \\
86-2 \\
86-2\end{array}$ & $\begin{array}{l}86-35-4 \\
\text { Piedmont }\end{array}$ & $\begin{array}{l}280 \\
224 \\
195 \\
184 \\
266 \\
260\end{array}$ & $\begin{array}{l}249 \\
145 \\
162 \\
131 \\
248 \\
188\end{array}$ & $\begin{array}{l}54.9 \\
58.5 \\
56.1 \\
56.7 \\
47.9 \\
47.9\end{array}$ & $\begin{array}{l}60.5 \\
63.2 \\
63.7 \\
65.1 \\
50.2 \\
50.7\end{array}$ & $\begin{array}{l}0.26 \\
0.17 \\
0.11 \\
0.08 \\
0.57 \\
0.56\end{array}$ & $\begin{array}{r}-0.01 \\
-0.09 \\
-0.12 \\
0.61 \\
0.54\end{array}$ & $\begin{array}{l}1.12 \\
0.97\end{array}$ & $\begin{array}{l}1.28 \\
0.80 \\
0.79 \\
1.35 \\
1.24\end{array}$ & $\begin{array}{r}13.3 \\
21.6 \\
22.4 \\
26.8 \\
6.2 \\
6.9\end{array}$ & $\begin{array}{r}10.1 \\
12.6 \\
12.3 \\
14.8 \\
6.0 \\
6.8\end{array}$ \\
\hline Control & & Pik-Red & 221 & 209 & 47.7 & 48.0 & 0.58 & 0.62 & 1.00 & 1.36 & 8.8 & 8.2 \\
\hline
\end{tabular}

${ }^{2} \mathrm{~L}$ value was measured as percent reflectance using a white standard as $100 \%$. Values for a and $b$ for the $a / b$ ratio were measured using a red standard surfacc and a Minolta CR-100 chromomcter. 'Lines listed in columns Parent 1 and Parent 2 are alc homozygotes and normal-ripening lines, respectively.

hybrid 'Pik-Red' (Harris-Moran Seed Co., Modesto, Calif.) was used as a control.

Hybrids and parent lines were grown in 1987 and 1988 in Freeville, N. Y., using a randomized complete block design. Each hybrid or parent line was represented by one row of six plants per block, in three blocks in 1987 , and by one row of 10 plants per block, in four blocks in 1988. Seed were planted in a greenhouse the first week of May, and the resulting plants were transplanted to the field in the first or second week of June. Standard fertilization, irrigation, and pest and weed management practices were used according to Cornell Recommendations for Commercial Vegetable Production (Ellerbrock et al., 1987).

Twenty fruit from each row were harvested at the breaker to $25 \%$ color stage, washed in a $0.3 \%$ sodium hypochlorite solution, and held at 20C. The plants in the field and the fruit being assayed were identified by row number only, in an effort to conduct a blind test. At harvest, and thereafter, it was not possible to discern the alc heterozygotes from the normal-ripening lines visually; however, ripe fruit of the alc homozygotes were visually identifiable as such.

The date at which each fruit reached the ripe stage was recorded, as classified by the U.S. standards for grades of fresh tomato (U.S. Dept. of Agriculture, 1973), and fruit weight, firmness, and color were measured on that date. Firmness was evaluated by resistance to deformation in units of $0.1 \mathrm{~mm}$ as measured with a penetrometer modified for deformation assays (Bourne, 1973), applying a $500 \mathrm{-g}$ weight for $5 \mathrm{sec}$ on the horizontal axis of the fruit (Mutschler, 1984b). With this technique, high deformation readings indicate soft fruit. For convenience, all firmness readings were converted to units of
$1 \mathrm{~mm}$. Color was measured with a CR-100 chromometer (Minolta Corp., Ramsey, N.J.) with an 8-mm light aperture and an attached DP-100 data processor. The instrument measures the percent reflectance ( $\mathrm{L}$ value) calibrated against a white standard surface set at $100 \%$ reflectance; the darker the color of the fruit, the lower the $\mathrm{L}$ value obtained. The a and $\mathrm{b}$ scales, which were calibrated with a red standard surface, provide the estimation of the $\mathrm{a} / \mathrm{b}$ ratio. Immature green tomatoes have an $\mathrm{a} / \mathrm{b}$ ratio less than 0 , and this ratio increases to zero and above as the fruit ripen toward a dark red. Values for individual tomatoes were the mean of three measurements around the circumference of the fruit.

Data from the 20 fruits were averaged for each block before analysis of variance (ANOVA). Univariate ANOVA was performed for fruit weight (grams), L value (percent), a/b ratio, firmness as measured by deformation (millimeters), and shelf life (days) using SAS software version 5.18. The ANOVA treatment levels consisted of the seven homozygous populations (four parental alc populations, two parental normal-ripening populations, and one control population) and the eight heterozygous $F_{1}$ populations. Bartlett's test for homogeneity of variances indicated that treatment variances were similar. Nonindependent, single degree-of-freedom contrasts were constructed to compare selected means of the normal-ripening populations and populations heterozygous and homozygous for alc.

Fruit weight. There were significant differences in weight between the alc and normal-ripening populations assayed in 1987 and 1988 (Tables 1 and 2, first contrast in both years). This result is not surprising, since the parental types represented a wide range of fruit weights. Fruit of the alc parents averaged more than $40 \mathrm{~g}$ lighter than those of the normal-ripening parents (Table 2), although alc line 86-261-6 weighed about the same as the normal-ripening parents. The normalripening lines used as parents had fruit weight similar to that of 'Pik-Red'.

There were no obvious effects of alc in the heterozygous condition on fruit weight and no pattern between weights of the $\mathrm{F}_{1} \mathrm{~S}$ vs. their parents in either year. In general the fruit weights of the $\mathrm{F}_{\mathrm{s}} \mathrm{s}$ were intermediate to those of the two parents; however, there were a few exceptions (Table 1). There were no differences between the $\mathrm{F}_{\mathrm{S}}$ and their normal-ripening parents in either year, except for 86-35-4 $\mathrm{F}_{\mathrm{s}}$ in 1988 , which were smaller than the normal-ripening parent. This difference probably occurred because 86-35-4 maintained its fruit weight better, whereas fruit of most lines and $\mathrm{F}_{1} \mathrm{~s}$ weighed less in 1988 (Table 1, comparisons 4 and 5 of 1988 in Table 2).

Fruit color. Fruit homozygous recessive for alc had significantly higher $\mathrm{L}$ values than fruit of the normal-ripening parents in both years (Tables 1 and 2), indicating that alc fruit was lighter in color. In contrast there were no significant differences between the normal-ripening parents and 'Pik-Red' in either year. The $\mathrm{F}_{1}$ readings were intermediate between the normal-ripening and alc homozygous parents; however, in all cases the $L$ values of the hybrid fruit resembled those of the normal-ripening parents more than those of the alc parent (Table 1). The $\mathrm{F}_{\mathrm{S}}$ were not signifilcantly different from their normal-ripening parent in either year (comparisons 4 and 5 of both years in Table 2). The $F_{1} s$ had significantly lower $L$ values than their alc parents in both years (comparisons 7-10 in Table 2), indicating darker fruit color.

The results of the $\mathrm{a} / \mathrm{b}$ ratios were very similar to those for the L values. Fruit homozygous recessive for alc had lower $\mathrm{a} / \mathrm{b}$ ratios than fruit of the normal-ripening parents in both years (Tables 1 and 2). In contrast, there were no differences between the normal-ripening parents and the normal-ripening control populations in either year. In all cases, the hybrid fruit were very similar in $\mathrm{a} / \mathrm{b}$ ratios to the normal-ripening parents (Table 1). The $F_{1} S$ were not significantly different from their normal-ripening parents in either year (comparisons 4 and 5 in both years in Table $2)$. However, the $F_{1} s$ had higher $a / b$ ratios than their alc parents in both years (comparisons 7-10 in both years in Table 2).

Considering both $\mathrm{L}$ values and $\mathrm{a} / \mathrm{b}$ ratios, there were no consistent effects of alc on visual color quality of heterozygous hybrids. The alc parent 86-261-6 had significantly better fruit color than the other alc hommozygous lines, and hybrids made using this line also tended to have better color than the other hybrids, although these differences were not large. Selection of the background into which alc is transferred may further improve these traits in heterozygous fruit.

Fruit firmness. 'Pik-Red' had an average deformation of 1.0 and $1.4 \mathrm{~mm}$ in 1987 and 1988 , respectively, values that correspond to deformation ratings of firm commercial varieties when first ripe, which are typically 


\begin{tabular}{|c|c|c|c|c|c|c|c|c|c|c|}
\hline \multirow[b]{3}{*}{ Year and comparisons made } & \multirow{2}{*}{\multicolumn{2}{|c|}{$\mathrm{Wt}(\mathrm{g})$}} & \multicolumn{4}{|c|}{ Fruit color } & \multirow{2}{*}{\multicolumn{2}{|c|}{$\begin{array}{c}\text { Deformation } \\
(\mathrm{mm})\end{array}$}} & \multirow{2}{*}{\multicolumn{2}{|c|}{$\begin{array}{c}\text { Shelf life } \\
\text { (days) }\end{array}$}} \\
\hline & & & \multicolumn{2}{|c|}{ L value (\%) } & \multicolumn{2}{|c|}{$\mathrm{a} / \mathrm{b}$ ratio } & & & & \\
\hline & $\mathbf{M S}^{\mathbf{z}}$ & Difference $^{y}$ & MS & Difference & MS & Difference & MS & Difference & MS & Difference \\
\hline 1988 & & & & & & & & & & \\
\hline $\begin{array}{l}\text { 1) alc vs. normal parents } \\
\text { 2) Piedmont vs. } 86-35-4 \\
\text { 3) Normal parents vs. Pik-red } \\
\text { 4) } 86-35-4 \text { vs. its } F_{1} s \\
\text { 5) Piedmont vs. its } F_{1} s \\
\text { 6) Piedmont } F_{1} s \text { vs. } 86-35-4 F_{1} s \\
\text { 7) } 86-261-6 \text { vs. its } F_{1} s \\
\text { 8) } 86-248-7 \text { vs. its } F_{1} s \\
\text { 9) } 86-269-8 \text { vs. its } F_{1} s \\
\text { 10) } 86-268-3 \text { vs. its } F_{1} s\end{array}$ & $\begin{array}{l}9057^{* * *} \\
4999^{* *} \\
114 \\
9823^{* * *} \\
16 \\
321 \\
5531^{* *} \\
4335^{* *} \\
483 \\
3466^{*}\end{array}$ & $\begin{array}{r}-44 \\
-54 \\
7 \\
63 \\
2 \\
-6 \\
46 \\
-40 \\
-14 \\
-36\end{array}$ & $\begin{array}{l}762.1^{* * *} \\
0.4 \\
14.7 \\
0.9 \\
0.0 \\
8.0 \\
332.3^{* * *} \\
453.4^{* * *} \\
440.2^{* * *} \\
595.2^{* * *}\end{array}$ & $\begin{array}{r}12.6 \\
0.5 \\
2.4 \\
0.6 \\
0.1 \\
-1.0 \\
11.2 \\
13.0 \\
12.8 \\
14.9\end{array}$ & $\begin{array}{l}1.772^{* * *} \\
0.006 \\
0.004 \\
0.001 \\
0.000 \\
0.007 \\
0.658^{* * *} \\
0.905^{* * *} \\
1.120^{* * *} \\
1.284^{* * *}\end{array}$ & $\begin{array}{r}-0.61 \\
-0.06 \\
-0.04 \\
0.02 \\
-0.01 \\
0.03 \\
-0.50 \\
-0.58 \\
-0.65 \\
-0.69\end{array}$ & $\begin{array}{l}5.13^{* * *} \\
0.25 \\
0.06 \\
0.14 \\
0.00 \\
0.22 \\
1.48^{* * *} \\
0.28 \\
3.93^{* * *} \\
4.84^{* * *}\end{array}$ & $\begin{array}{r}-0.33 \\
-0.12 \\
-0.05 \\
0.08 \\
0.01 \\
0.05 \\
-0.24 \\
-0.10 \\
-0.38 \\
-0.43\end{array}$ & $\begin{array}{l}174.7^{* * *} \\
1.0 \\
8.1^{*} \\
30.7^{* * *} \\
34.6^{* * *} \\
2.6 \\
1.9 \\
35.3^{* * *} \\
7.1^{*} \\
54.2^{* * *}\end{array}$ & $\begin{array}{r}6.1 \\
0.8 \\
-1.8 \\
-3.5 \\
-3.3 \\
-0.6 \\
0.8 \\
3.6 \\
1.6 \\
4.5\end{array}$ \\
\hline
\end{tabular}

${ }^{2}$ Mean squares are calculated from SAS Type III sum of squares.

yEstimated differences between population means. Differences were calculated by subtracting the value of the contrast means to the right of "vs." in the first column from the value of the contrast mean to the left. The mean differences have the same significance $\left(\mathrm{H}_{0}\right.$ : the difference is zero) as the mean squares.

$*, * * * * *$ Significant at $P<0.05,0.01$, or 0.001 , respectively.

0.9 to $1.1 \mathrm{~mm}$ (M.A.M., unpublished). Soft varieties have readings as high as $2.0 \mathrm{~mm}$. In general, alc homozygotes have exceptionally firm fruit, with average readings of 0.4 to $0.6 \mathrm{~mm}$, depending on the background of the line. This is also the range of firmness readings for green tomatoes. Fruit of the landrace Alcobaca, the source of the alc mutant, are sometimes softer than this range due to extreme puffiness of the fruit.

The fruit of the alc homozygous parents had lower deformation readings than fruit of the normal-ripening parents in both years (Tables 1 and 2). There were no differences between the normal-ripening parents and the normal-ripening control, 'Pik-Red', in either year. In both series of crosses, the $\mathrm{F}_{1} \mathrm{~s}$ were not significantly different from their normalripening parents in either year (comparisons 4 and 5 for both years in Table 2). Generally, the $\mathrm{F}_{1} \mathrm{~s}$ were softer than the alc parents, with the exception of the $\mathrm{F}_{1} \mathrm{~s}$ with 86-248-7 in 1988 , in which year the fruit of the parent line 86-248-7 were unusually soft.

Shelf life. The fruit of 'Pik-Red' have a longer shelf life than the normal parents used. This difference, which was significant in 1988 but not in 1987, illustrates some of the variability available for shelf life that could be exploited in addition to the use of ripening mutants.

Fruit homozygous recessive for alc had longer shelf life than fruit of the normalripening parents in both years (Table 1, comparison 1 for both years in Table 2). Fruit of the alc line 86-261-6 stored longer than that of the normal-ripening lines but had a shorter average shelf life than fruit of the other alc lines. Since 86-261-6 is also the line that had superior color, the factor(s) that decreased the negative effect of the homozygous alc condition of fruit color may also be responsible for the decreased shelf life of the fruit of this line.

The $\mathrm{F}_{1} \mathrm{~s}$ generally had shorter shelf life than their alc parents in both years (Table 2, comparisons 7-10). The exception was the lack of significance between the parent 86261-6 and its $\mathrm{F}_{1} \mathrm{~s}$; however, this alc parent had the shortest shelf life. In both series of crosses and in both years, the $\mathrm{F}_{1} \mathrm{~s}$ had longer storage life than their normal-ripening parent (Table 2, comparisons 4 and 5). The average increase in shelf life of fruit of the $\mathrm{F}_{1}$ hybrids heterozygous for alc was 3.6 days, i.e., $60 \%$ longer than that of the normal-ripening parents, with the increase in shelf life ranging from 2 to 8 days. Factors that may have affected the shelf life of the hybrids include firmness of the parents used and susceptibility to fruit cracking, which makes the fruit more susceptible to infection. Since shelf life was increased significantly compared to that of normal-ripening lines, but firmness was not increased, some factor in addition to firmness is likely to be involved in increased shelf life.

The use of hybrids heterozygous for alc has potential for extending the shelf life of fresh-market tomatoes. The concept of use of the alc ripening mutant is similar to the use of nor or rin heterozygotes for extending tomato fruit shelf life. The alc heterozygous hybrids have on average a $60 \%$ increase in shelf life over normal-ripening tomato lines. In the heterozygous condition, alc has no deleterious effects on fruit weight and color, and positive or no effects on fruit firmness.
The background into which alc is introduced is important in determining the magnitude of the resulting increase in shelf life. Of the alc lines used for hybrid production, those with 86-248-7 as a parent had better shelf life but slightly poorer color than those with the other alc lines as parents, although these differences may not be commercially significant. Hybrids with 86-269-8 as a parent generally had better shelf life in 1988 and did not suffer from poorer color in either year. By using hybrids with increased shelf life and a marketing scheme in which tomatoes are harvested after the onset of color development and are handled appropriately, an opportunity exists for reliably and consistently improving tomato fruit quality. Seed of any of the alc lines is available upon request.

\section{Literature Cited}

Aly, M.A.A., A.S. Beltagy, and G.E. Hobson. 1986a. Comparison between three tomato lines (Rin, Rin, Rin rin, and rin rin) in ACC content loss in firmness and loss in weight. Acta Hort. 190:183-190.

Aly, M.A.A., G.E. Hobson, and A.S. Beltagy. 1986b. Effect of introducing the mutant in rin allele on some characters of tomato fruit during storage. Acta Hort. 190: 197-207.

Bourne, M.C. 1973. Use of the penetrometer for deformation testing of foods. J. Food Sci. 38:720-721.

Buescher, R. W., W.A. Sistruck, E.C. Tigchelaar, and T.J Ng. 1976. Softening, pectolytic activity, and storage life of rin and nor tomato hybrids. HortScience 11:603-604.

Ellerbrock, L. A., R.F. Becker, R.R. Bellinder, D.E. Halseth, R.A. Kline, P.L. Minnotti, A.A. Muka, J.S. Sieczka, W.M. Tingey, L.D. Topoleski, D.T. Warholic, H.C. Wien, D.A. Wil- 
cox-Lee, D.W. Wolfe, and T.A. Zitter. 1987. Tomato production, p. 88-93. Cornell recommendations for commercial vegetable production. Cornell Univ., Ithaca, N.Y.

Gardner, R.G. 1985. 'Piedmont' tomato. HortScience 20:960-961.

Kader, A.A., M.A. Stevens, M. Albright-Holton, L.L. Morris, and M. Algazi. 1977. Effect of fruit ripeness when picked on flavor and composition on fresh market tomatoes. J. Amer. Soc. Hort. Sci. 102:724-731.

Kinzer, S. M., S.J. Schwager, and M.A. Mutschler. 1990. Mapping of ripening-related or -specific cDNA clones of tomato (Lycopersicon esculentum). Theor. Applied Genet. 79:489-496. Kopeliovitch, E., Y. Mizrahi, H.D. Rabinowitch, and N. Kedar. 1982. Effects of the tomato rip- ening mutant genes rin and nor on the flavor of tomato fruit. HortScience 107:361-364.

Kopeliovitch, E. and H.D. Rabinowitch. 1979. The potential of ripening mutants for extending the storage life of the tomato fruit. Euphytica 28:99-104.

McGlasson, W.B. J.H. Last, K.J. Shaw, and S.K Meldrum. 1987. Influence of the non-ripening mutant rin and nor on the aroma of tomato fruits. HortScience 22:632-634.

McGlasson, W. D., J.B. Smueghy, L.L. Morris R.L. McBride, and D.J. Best. 1983. Yield and evaluation of $F_{1}$ tomato hybrids incorporating the nonripening nor gene. Austral. J. Expt. Agr. Animal Husbandry 23:106-112.

Mutschler, M.A. 1984a. Inheritance and linkage of the 'Alcobaca' ripening mutant in tomato. J. Amer. Soc. Hort. Sci. 109:500-503.

Mutschler, M.A. 1984b. Ripening and storage characteristics of the 'Alcobaca' ripening mutant in tomato. J. Amer. Soc. Hort. Sci. 109:504507.

Mutschler, M.A., M. Guttieri, S. Kinzer, D. Grierson, and G. Tucker. 1988. Changes in ripening processes in tomato conditioned by the alc mutant. Theor. Applied Genet. 76:285-292.

Tigchelaar, E. C., W.B. McGlasson, and R.W Buescher. 1978. Genetic regulation of tomato fruit ripening. HortScience. 13:508-513.

U.S. Dept. of Agriculture. 1973. United States standards for grades of fresh tomates. U.S. Dept. Agr. Agr. Mktg. Serv., Washington, D.C. 